A. Cascio $\cdot$ C. Colomba $\cdot$ S. Antinori $\cdot$ M. Orobello

D. Paterson $\cdot$ L. Titone

\title{
Pediatric Visceral Leishmaniasis in Western Sicily, Italy: A Retrospective Analysis of 111 Cases
}

Published online: 13 April 2002

(C) Springer-Verlag 2002

\begin{abstract}
The clinical and epidemiological characteristics of 111 consecutive cases of visceral leishmaniasis identified from 1980 to 2000 in a Sicilian pediatric hospital were analyzed retrospectively. The mean age of the patients was 1.7 years. All children were HIV negative, but $15 \%$ were severely malnourished. Fever and splenomegaly were present in all cases and hepatomegaly in $101(90.1 \%)$ cases. Thrombocytopenia and anemia were both observed in $78(70.2 \%)$ cases and leukopenia in 47 $(42.3 \%)$ cases. A bone marrow aspirate was obtained in all cases; Leishmania amastigotes were detected in 89 $(80.2 \%)$ cases. Initial treatment consisted of meglumine antimoniate in $99(89.2 \%)$ patients and amphotericin B in $12(10.8 \%)$ patients. Only two children treated with meglumine antimoniate relapsed. The findings highlight the differences between the cases of visceral leishmaniasis observed in the Mediterranean basin and those observed in other regions. The use of the term "Mediterranean visceral leishmaniasis", rather than the term "kalaazar", is proposed for cases observed in the Mediterranean area.
\end{abstract}

\footnotetext{
A. Cascio $(\varangle) \cdot$ C. Colomba $\cdot$ S. Antinori · M. Orobello

L. Titone

Istituto di Patologia Infettiva e Virologia,

Ospedale "G. Di Cristina", Università di Palermo,

Piazza Montalto 8, 90134 Palermo, Italy

e-mail: acascio@unime.it

Tel.: +39-091-6887613, Tel.: +39-090-2212031

Fax: +39-091-6887613
}

\section{Paterson}

Infectious Disease Section,

University of Pittsburgh Medical Center Overseas, Palermo, Italy

Present Address:

A. Cascio,

Associazione Italiana per la Lotta contro le Malattie Infettive (AILMI), c/o Scuola di Specializzazione in Malattie Infettive, Universitá di Messina, Via Consolare Valeria 1, 98125 Messina, Italy

\section{Introduction}

Visceral leishmaniasis (VL) is endemic in areas bordering the Mediterranean Sea (Spain, Italy, France, Greece, Morocco, Tunisia), where it is caused by the protozoan Leishmania infantum and is transmitted by the bite of hematophagous sandflies belonging to Phlebotomus spp. The dog constitutes the proven reservoir of the infection.

Sicily is the largest island in the Mediterranean Sea. It was recently estimated that approximately $47 \%$ of the Sicilian population live in areas at risk for Leishmania infection, these areas consisting mainly of rural areas, small villages, or peripheral districts of towns where the vector sandfly species are more abundant. During the 1987-1995 period, the annual incidence of VL in the general population was 6 cases per 1,000,000 residents [1].

In comparison with the past, when VL was typically observed more frequently in children, the current agerelated epidemiologic features observed in Sicily reflect those reported for other Mediterranean regions of $\mathrm{Eu}-$ rope, such as France, Spain, and Greece, where the ratio of childhood to adult cases is approximately 1:1 [1,2,3].

Pentavalent antimonial drugs have been used for many decades as standard treatment for VL [4]. They have been used extensively in children and have been demonstrated to be safe and effective. During the last decade, the emergence of Leishmania strains resistant to pentavalent antimonials and the occurrence of side effects have prompted the evaluation of other drugs, including pentamidine and lipid formulations of amphotericin B [4].

We analyzed retrospectively the epidemiologic, clini$\mathrm{cal}$, and therapeutic features of 111 children affected by VL and admitted consecutively to our hospital over a 21year period (1980-2000). This is the hospital where antimonial drugs were employed for the first time in the therapy of VL, in the early part of the $20^{\text {th }}$ century [5]. 
Table 1 Clinical features of 111 children with visceral leishmaniasis

a Mild enlargement of the small lymph nodes in the cervical chain of 13 patients was not considered true lymphadenopathy related to visceral leishmaniasis

\begin{tabular}{lc}
\hline Clinical feature & Finding \\
\hline Median duration of disease before admission (range) & 15 days (2 days-7 months) \\
Fever [no. of cases $(\%)$ ] & $111(100)$ \\
Splenomegaly [no. of cases $(\%)]$ & $111(100)$ \\
Extent of spleen enlargement [median distance below & $4 \mathrm{~cm}(2-13 \mathrm{~cm})$ \\
$\quad$ left costal margin (range)] & $101(91)$ \\
Hepatomegaly [no. of cases $(\%)]$ & $3 \mathrm{~cm}(0-11 \mathrm{~cm})$ \\
Extent of liver enlargement [median distance below & 2 \\
$\quad$ the right costal margin (range)] & 0 \\
Skin lesions (no. of cases) & \\
Lymphadenopathy (no. of cases) & a \\
\hline
\end{tabular}

\section{Subjects and Methods}

The G. Di Cristina Hospital in Palermo is the largest children's hospital in Sicily. It is a tertiary-care university hospital with 350 beds serving a population of about 1,000,000 in the Palermo district; furthermore, it acts as referral pediatric center for all of western Sicily. In this study, the guidelines of the G. Di Cristina Hospital were followed in the conduct of clinical research.

All children aged $0-14$ years diagnosed with VL consecutively from January 1980 through December 2000 were included in the study. The patient's clinical histories were stored in a database that included their demographic characteristics (age, sex), clinical and laboratory findings recorded on admission and during hospitalization, therapeutic interventions, and clinical outcome.

Diagnosis of VL was established if patients met at least one of the following criteria:

- Presence of clinical signs and symptoms compatible with VL (fever, hepato-splenomegaly, pancytopenia, hypergammaglobulinemia) and detection of serum Leishmania antibodies by an immunofluorescent antibody test (IFAT) at a titer $\geq 1: 40$;

- Demonstration of the presence of Leishmania parasites in the bone marrow or spleen aspirates by microscopy and/or culture.

Fever was defined as a temperature $\geq 38^{\circ} \mathrm{C}$; anemia was defined as a hemoglobin value of $<9 \mathrm{mg} / \mathrm{dl}$; leukopenia was defined as $<4,000$ leukocytes $/ \mu 1$, and thrombocytopenia as $<150,000$ platelets/ $\mu$ l.

Patients were treated with meglumine antimoniate (Glucantim; Aventis Pharma, Italy) or with liposomal amphotericin B (LAmB) (AmBisome; Gilead, USA). Six of these patients had been enrolled in clinical trials $[6,7,8]$. Meglumine antimoniate was administered intramuscularly, generally for 21 days at a dosage of $560 \mathrm{mg} / \mathrm{m}^{2}$ of $\mathrm{Sb}^{\mathrm{V}}$ after a gradually increasing daily dose during the first 3-4 days of therapy. Other schedules such as a 28-day course at a dosage of pentavalent antimony of $20 / \mathrm{mg} / \mathrm{kg} / \mathrm{day}$, two 15-day courses separated by 10-15 days without therapy, and others were adopted for patients enrolled in clinical trials or were based on the individual physician's preference. L-AmB was used for patients enrolled in clinical trials and for patients that did not respond to antimonial treatment or who experienced side effects or relapse after antimonial therapy. L-AmB was administered intravenously at a dosage of $3 \mathrm{mg} / \mathrm{kg}$ for 10 consecutive days (total dose, $30 \mathrm{mg} / \mathrm{kg}$ ) or on days $1,2,3,4,5$, and 10 (total dose, $18 \mathrm{mg} / \mathrm{kg}$ ) or on days $1,2,3,4$, and 10 (total dose, $15 \mathrm{mg} / \mathrm{kg}$ ).

Clinical response was assessed at the completion of treatment and was defined as cure (defervescence, restoration of laboratory parameters, or reduction of spleen size) or failure (persistence or worsening of clinical and laboratory findings). Relapse was defined as the reappearance of signs and symptoms of disease in association with identification of amastigote forms of Leishmania in bone marrow smears after initial successful treatment. Most of the patients were monitored at the outpatient clinic of the hospital for at least 1 year after treatment was completed.

IFAT has been performed routinely since 1989 using a commercial kit (Leishmania -Spot IF; bioMérieux, France). Cultures were performed by seeding bone marrow aspirates into a semisolid blood-agar-based medium (Sloppy Evans medium) generously supplied by Istituto Superiore di Sanità in Rome.

Positive cultures were sent to the Istituto Superiore di Sanità, where Leishmania strains were characterized by Dr. M. Gramiccia by means of starch electrophoretic analysis of 15 isoenzymes, using the techniques and zymodeme nomenclature of the World Health Organization Collaborating Center (Montpellier, France).

\section{Results}

From January 1980 to December 2000, 111 children were diagnosed with VL. Admissions averaged five per year, without any seasonal variation. The patients' median age was 1.7 years (range, 4.5 months -11.7 years); 19 (17.1\%) patients were aged $<12$ months. Fifty-six (50.4\%) were males. No child was HIV positive. Analysis of the nutritional status of the patients showed that 17 $(15.3 \%)$ were below the tenth percentile on the weightfor-age growth chart. Two (1.8\%) patients had an underlying disease at hospital admission: one was affected by Wilson's disease, the other one by pseudomembranous conjunctivitis. Twenty-five $(22.5 \%)$ patients had a concurrent bacterial or viral infection, including acute otitis media (7 patients), respiratory infections ( 8 patients, upper respiratory infection; 5 patients, bronchitis; and 3 patients, pneumonia), and tonsillitis (2 patients). One girl was an immigrant from Ghana. In all but one case, the disease was contracted in western Sicily. Eighty-nine $(80 \%)$ patients lived in districts that were located near the foothills of mountains bordering the city or within the city itself. The median time from the onset of symptoms to hospital admission was 15 days (range, 2 days7 months). Fever and splenomegaly were present at admission in all patients (Table 1).

Interestingly, in two cases a small skin lesion on the face was associated with VL and preceded the onset of full-blown disease. In both cases numerous intracellular and extracellular Leishmania amastigotes were present on the smears obtained from the lesions (Fig. 1a).

The most frequently encountered hematological findings were thrombocytopenia and anemia, both of which were observed in $80.4 \%$ of the patients. Leukopenia was found in $43.1 \%$ of the patients, and $<500$ neutrophils were present in $9.1 \%$ of the patients. Pancytopenia was present in six (5.7\%) patients, and both leukopenia and thrombocytopenia without anemia in $28(26.9 \%)$ pa- 


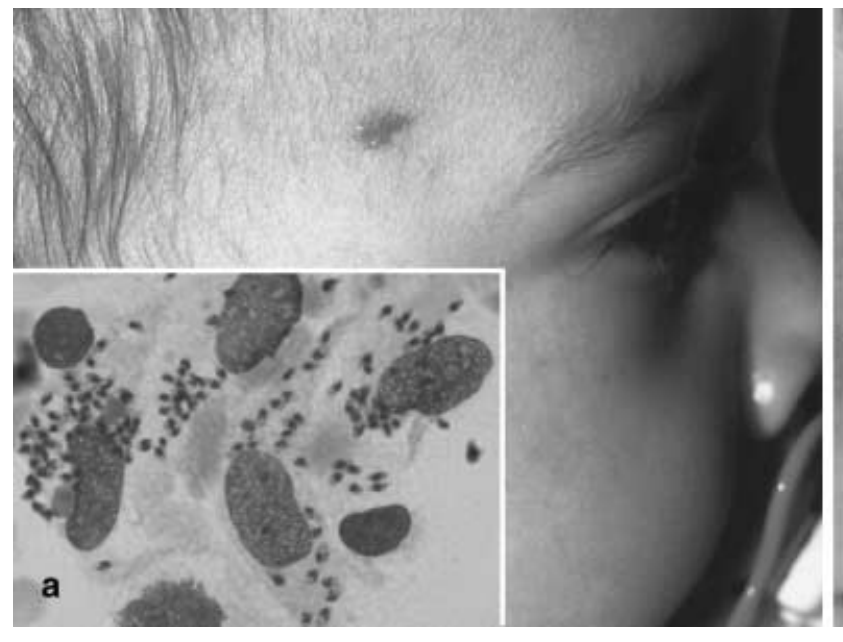

Fig. 1 a Small, reddish macula observed on the face of a child with visceral leishmaniasis caused by a viscerotropic strain (MON1) of Leishmania infantum. Inset: Giemsa-stained smear showing intracellular and extracellular Leishmania amastigotes (original magnification, $\times 1000$ ) $\mathbf{b}$ Typical presentation of Old World cutaneous leishmaniasis (oriental sore, caused by a dermotropic strain of Leishmania infantum) in the Sicilian region

Table 2 Hematological and biochemical features of 111 children with visceral leishmaniasis

\begin{tabular}{lc}
\hline Variable & Median value (range) \\
\hline Erythrocyte count $\left(\times 10^{6}\right.$ cells $\left./ \mu \mathrm{l}\right)$ & $3.7(1.9-5)$ \\
Hemoglobin $(\mathrm{g} / \mathrm{dl})$ & $7.8(3.8-12.7)$ \\
Leukocyte count $\left(\times 10^{3}\right.$ cells $\left./ \mu \mathrm{l}\right)$ & $4.3(1.6-10.9)$ \\
Neutrophil count $\left(\times 10^{3}\right.$ cells $\left./ \mu \mathrm{l}\right)$ & $1(0.2-3.7)$ \\
Platelets $\left(\times 10^{3}\right.$ cells $\left./ \mu \mathrm{l}\right)$ & $110(12-362)$ \\
Erythrocyte sedimentation rate $(\mathrm{mm} / \mathrm{h})$ & $73(9-138)$ \\
C-reactive protein $(\mathrm{mg} / 100 \mathrm{ml})$ & $2.3(0.3-18.2)$ \\
Total protein $(\mathrm{g} / \mathrm{dl})$ & $7.3(4.5-10.4)$ \\
Albumin $(\mathrm{g} / \mathrm{dl})$ & $3.3(1.4-5.3)$ \\
Gammaglobulin $(\mathrm{g} / \mathrm{dl})$ & $2.3(0.6-6.6)$ \\
Aspartate aminotransferase $(\mathrm{IU} / \mathrm{l})$ & $53(19-847)$ \\
Alanine aminotransferase $(\mathrm{IU} / \mathrm{l})$ & $33(8-497)$ \\
\hline
\end{tabular}

tients. Fifteen $(13.5 \%)$ patients required blood transfusion due to anemia. The albumin value was $<3 \mathrm{~g} / \mathrm{dl}$ in $31.1 \%$ of the patients. In $22.4 \%$ of the patients, the albumin value was higher than the globulin value (albu$\mathrm{min} /$ globulin inversion). A value of aspartate aminotransferase and of alanine aminotransferase $>80 \mathrm{IU} / 1$ was reported in $33.3 \%$ and $23.6 \%$, respectively (Table 2 ).

A bone marrow aspirate was obtained from all patients, and Leishmania amastigotes were detected in 89 $(80.2 \%)$ cases. In one case, after two negative examinations of bone marrow, a splenic aspirate was obtained; examination revealed Leishmania parasites. Culture from bone marrow aspirate was performed in 41 cases and was positive in 31 (75.6\%). Leishmania infantum isolates were isoenzymatically characterized: the zymodemes identified were MON 1 in 24 cases and MON 27 and MON 80 in 1 case each. The remaining five strains could not be characterized due to bacterial contamination.

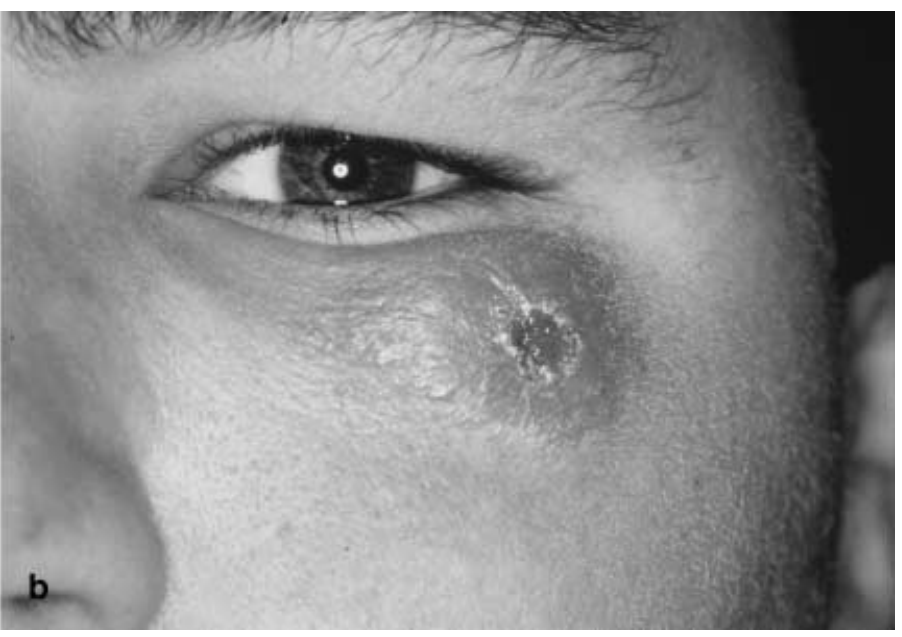

IFAT was performed in $84(75.7 \%)$ cases; it gave a false-negative result in only 2 cases (in these cases, the diagnosis was made by microscopy). The geometric mean titer of anti-Leishmania antibody was 227 (range, $0-5,120)$.

Diagnosis of visceral leishmaniasis was established by direct microscopy of bone marrow together with positive IFAT in 60 patients; by means of IFAT alone in 22 (in 1 of these, diagnosis was confirmed by a positive culture), and by microscopy alone in 29. Diagnosis was made a median of 2 days (range, $0-23$ days) after admission.

Ninety-nine $(89.2 \%)$ patients were treated initially with meglumine antimoniate and $12(10.8 \%)$ patients with L-AmB. Patients were followed-up at the outpatient clinic for a median of 1 year (range, 6 months -3 years) after treatment was completed. Of the 99 patients treated with meglumine antimoniate, 1 was still febrile after 6 days, so treatment was switched to L-AmB. Two patients relapsed within the next 100 days and then were treated with L-AmB; one had been treated with $20 \mathrm{mg} / \mathrm{kg}$ for 28 days, the other one with $25 \mathrm{mg} / \mathrm{kg}$ per 30 days in two 15-day courses. Of the patients treated with L-AmB, one had been treated for VL with meglumine antimoniate 1 year previously in another part of Italy (Ancona). This case should be considered a relapse. All patients treated with L-AmB recovered, and none relapsed (Table 3). The cutaneous lesion (Fig. 1a) associated with a case of VL persisted after six doses (on day 10) of L-AmB, even though it became slightly less reddish than observed initially. Scarce amastigotes were still present on the smear, so a 10-day course of intralesional meglumine antimoniate (about $20 \mathrm{mg}$ of $\mathrm{Sb}^{\mathrm{V}}$, given on alternate days) was administered, which resulted in complete resolution of the skin lesion.

Adverse effects while receiving meglumine antimoniate were observed in 16 patients, including rash (3 patients) and dry cough (13 patients). All adverse effects but one (the severe urticarial rash) were transient and self-limited and did not require interruption of treatment. No adverse effects were detected in the 16 patients treated with L-AmB (only a transient rash on day 9 of therapy, possibly not related to therapy). 
Table 3 Treatment and outcome of the 111 children with visceral leishmaniasis

\begin{tabular}{|c|c|c|c|c|c|}
\hline Drug and dosage & Duration of therapy & No. of courses of therapy & $\begin{array}{l}\text { No. of } \\
\text { cases }\end{array}$ & $\begin{array}{l}\text { Clinical } \\
\text { response }\end{array}$ & $\begin{array}{l}\text { No. of } \\
\text { relapses }\end{array}$ \\
\hline \multirow{3}{*}{$\begin{array}{l}\text { Meglumine antimoniate; } \\
\text { median } \mathrm{Sb}^{\vee} 23.5 \mathrm{mg} / \mathrm{kg} / \text { day } \\
\text { (range, } 14-30.2 \mathrm{mg} / \mathrm{kg} / \text { day) }\end{array}$} & $\begin{array}{l}<18 \text { days (median, } 14.5 \\
\quad \text { range, } 2-17 \text { ) }\end{array}$ & $\begin{array}{l}1 \text { course, } n=19 \text { patients; } \\
2 \text { courses, } n=2 \text { patients }\end{array}$ & 21 & $19 / 21^{\mathrm{a}}$ & 0 \\
\hline & $\begin{array}{l}18-24 \text { days (median, } 21 ; \\
\text { range, } 18-24)\end{array}$ & $\begin{array}{l}1 \text { course, } n=50 \text { patients; } \\
2 \text { courses, } n=15 \text { patients }\end{array}$ & 65 & $65 / 65$ & 0 \\
\hline & $\begin{array}{l}>24 \text { days (median, } 28 \\
\text { range, } 25-30)\end{array}$ & $\begin{array}{l}1 \text { course, } n=8 \text { patients; } \\
2 \text { courses, } n=5 \text { patients }\end{array}$ & 13 & $13 / 13$ & $2 / 13$ \\
\hline \multirow{3}{*}{$\begin{array}{l}\text { Liposomal AmB; } \\
3 \text { mg/kg/day }\end{array}$} & 5 days (4+1 on day 10 ) & & 2 & $2 / 2$ & 0 \\
\hline & 6 days $(5+1$ on day 10$)$ & & $11^{\mathrm{b}}$ & $11 / 11$ & 0 \\
\hline & 10 days & & $3^{c}$ & $3 / 3$ & 0 \\
\hline
\end{tabular}

a Two patients were switched from meglumine antimoniate to liposomal amphotericin B: 1 on day 6 of meglumine antimoniate treatment because clinical and laboratory findings had worsened, and 1 because of adverse reaction to meglumine antimoniate (severe urticarial rash after the second dose)

A reduction of spleen size up to half of the size initially palpated was observed a median of 10 days (range, 4-28 days) after treatment was begun. Overall, patients became afebrile a median of 4 days (range, 1-9 days) after treatment was initiated, whereas hematological restoration occurred a median of 12 days later (range, 9-30 days).

Twelve patients developed nosocomial infections: gastroenteritis (5 patients, caused by rotavirus in 3), chickenpox (1 patient), measles (1 patient), urinary tract infection (1 patient), and maculopapular exanthema caused by infection with human herpesvirus 6 (4 patients).

\section{Discussion}

The different forms of cutaneous leishmaniasis (i.e., cutaneous leishmaniasis, diffuse cutaneous leishmaniasis, and mucocutaneous leishmaniasis) are classified according to their epidemiology and clinical presentation [9]. Although VL acquired in the Mediterranean area has a different epidemiology and clinical presentation than that acquired in India or in other regions, all forms of VL are generally still referred to using the Hindi term "kalaazar", even in the latest edition of the two major textbooks of infectious and tropical diseases [9, 10]. Nevertheless, there are many differences between the disease acquired in the Mediterranean basin and other forms contracted elsewhere. These include the Leishmania species involved, the lack of post kala-azar dermal leishmaniasis, and the absence of skin hyperpigmentation (Table 4). Therefore, we believe that the term "kalaazar" and VL should not be used interchangeably for cases observed in the Mediterranean basin.

As in other case series describing VL acquired in the Mediterranean area [13, 14, 15], VL in Sicily involved mainly young children: the median age of our patients was 1.7 years, and $26.1 \%$ of the children were younger b Includes the two cases described above in footnote " $a$ "

c Includes the two cases that relapsed after antimonial therapy than 12 months. The main clinical and laboratory findings were also similar to those reported in the other Mediterranean countries [13, 14, 15].

A critical issue we would like to highlight is the appearance of lymphadenopathy during the course of VL; this is probably a quite common feature in Sudan (84\%) $[16,17]$, but it is rarer in the Mediterranean basin (36-39\%) [13, 14]. Furthermore, in our experience, except for lymphadenopathy of the small posterior cervical lymph nodes, which is a very common but nonspecific finding among children 2-14 years of age, lymphadenopathy was not found in any case. It would be very useful to know if, in the more recently reported pediatric series from the Mediterranean basin [13, 14], the finding of lymphadenopathy was definitely correlated to VL or, as we suppose, it was an occasional finding unrelated to the disease. In the future, we suggest that authors describing VL report the entity and the sites involved in the case of lymphadenopathy.

In contrast to what was reported in the last edition of the Mandell textbook [9], i.e., that "the presence of a hard spleen suggests a hematologic disorder or other diagnosis such as schistosomiasis", the spleen was hard in almost all of our patients. In fact, on the basis of the above misleading information, several of our patients were initially admitted to the hematologic department.

In two cases we observed a small, noninfiltrated lesion on the skin in which many Leishmania amastigotes were seen by microscopy. This kind of lesion preceding VL must be differentiated from the lesions of the typical cutaneous leishmaniasis that occurs in our region (known as "oriental sore" or dry form), which is caused by dermotropic strains of Leishmania infantum. It presents as a firm, painless, slow-growing, infiltrated papule and forms a well-circumscribed central ulceration with very few amastigotes (Fig. 1b) [18]. To the best of our knowledge, there are only two previous reports of skin involvement preceding overt VL in the Mediterranean area $[19,20]$. 
Table 4 Characteristic of the four forms of visceral leishmaniasis observed worldwide in otherwise immunocompetent patients

\begin{tabular}{|c|c|c|c|c|}
\hline Characteristic & $\begin{array}{l}\text { Mediterranean } \\
\text { visceral } \\
\text { leishmaniasis }\end{array}$ & $\begin{array}{l}\text { American } \\
\text { visceral } \\
\text { leishmaniasis }\end{array}$ & Kala-azar & African kala-azar \\
\hline $\begin{array}{l}\text { Main geographical } \\
\text { area } \\
\text { Epidemiology } \\
\text { Cycle }\end{array}$ & $\begin{array}{l}\text { Mediterranean basin } \\
\text { endemic } \\
\text { zooanthroponosis }^{\mathrm{a}}\end{array}$ & $\begin{array}{l}\text { northeast Brazil, } \\
\text { Central America } \\
\text { endemic } \\
\text { zooanthroponosis }\end{array}$ & $\begin{array}{l}\text { India, Pakistan, Nepal, } \\
\text { northern and southern China } \\
\text { endemic/epidemic } \\
\text { anthroponosis }\end{array}$ & $\begin{array}{l}\text { Sudan, Kenya, } \\
\text { Horn of Africa } \\
\text { endemic/epidemic } \\
\text { zooanthroponosis/ } \\
\text { anthroponosis? }\end{array}$ \\
\hline $\begin{array}{l}\text { Reservoir } \\
\text { Causative } \\
\text { Leishmania species }\end{array}$ & $\begin{array}{l}\text { dogs, foxes, jackals } \\
\text { L. donovani infantum }\end{array}$ & $\begin{array}{l}\text { dogs, foxes, opossums } \\
\text { L. donovani chagasi }\end{array}$ & $\begin{array}{l}\text { humans } \\
\text { L. donovani donovani }\end{array}$ & $\begin{array}{l}\text { rodents? dogs? humans? } \\
\text { L. donovani donovani }\end{array}$ \\
\hline $\begin{array}{l}\text { Vector species } \\
\text { and natural habitat }\end{array}$ & $\begin{array}{l}\text { Phlebotomus perniciosus, } \\
\text { Phlebotomus. ariasi; } \\
\text { domestic }\end{array}$ & $\begin{array}{l}\text { Lutzomyia longipalpis; } \\
\text { rural, peridomestic }\end{array}$ & $\begin{array}{l}\text { Phlebotomus argentipes; } \\
\text { rural }\end{array}$ & $\begin{array}{l}\text { Phlebotomus orientalis, } \\
\text { Phlebotomus martini; rural }\end{array}$ \\
\hline $\begin{array}{l}\text { Male/female ratio } \\
\text { Age of patients } \\
\text { usually affected }\end{array}$ & $\begin{array}{l}1: 1 \\
<5 \text { years }^{\mathrm{c}}\end{array}$ & $\begin{array}{l}\text { male }>\text { female } \\
\text { young children }\end{array}$ & $\begin{array}{l}6: 1 \\
\text { young adults }\end{array}$ & $\begin{array}{l}? \\
\text { young adults? }\end{array}$ \\
\hline \multicolumn{5}{|l|}{ Clinical manifestations } \\
\hline $\begin{array}{l}\text { Fever } \\
\text { Splenomegaly } \\
\text { Hepatomegaly } \\
\text { Skin } \\
\text { hyperpigmentation }\end{array}$ & $\begin{array}{l}95-100 \% \\
95-100 \% \\
\sim 70 \% \\
\text { no }\end{array}$ & $\begin{array}{l}95-100 \% \\
95-100 \% \\
\sim 70 \% \\
\text { no }\end{array}$ & $\begin{array}{l}95-100 \% \\
95-100 \% \\
\sim 75 \% \\
70 \%\end{array}$ & $\begin{array}{l}95-100 \% \\
95-100 \% \\
\sim 75 \% \\
\text { yes }\end{array}$ \\
\hline Lymphadenopathy & $0-39 \%$ & $?$ & $5 \%$ & $84 \%$ \\
\hline $\begin{array}{l}\text { Occurrence of } \\
\text { post-kala-azar dermal } \\
\text { leishmaniasis }\end{array}$ & no & no & $\begin{array}{l}6-20 \% ;<2 \text { years up to } \\
20 \text { years after initial } \\
\text { infection }\end{array}$ & $\begin{array}{l}2-5 \% \text {; shortly after } \\
\text { treatment }\end{array}$ \\
\hline $\begin{array}{l}\text { Resistance to } \\
\text { antimonial agents }\end{array}$ & rare & rare & frequent & frequent \\
\hline
\end{tabular}

a Evidence exists that, among HIV-infected patients, this form could be an anthroponosis [11]

$\mathrm{b}$ Biochemical and genetic studies indicate that Leishmania donovani chagasi and Leishmania donovani infantum are very similar (if not identical), and the two names must be regarded as synonyms. It is possible that the organism was brought to the New World by the dogs of the conquistadors and early settlers [10, 12].

We believe that at least a proportion of cases of VL among children are preceded by a very small lesion, generally considered a banal mosquito bite (even if it lasts for a longer time), and it would be useful in the future to investigate this point and to accurately examine the skin of VL patients.

As far as therapy of VL is concerned, pentavalent antimonials are still indicated as the drug of choice due to their availability, low cost, and efficacy. Although it is not feasible to make direct comparisons between the treatment regimens due to several possible selection biases, we found that a 21-day course of meglumine antimoniate $560 \mathrm{mg} / \mathrm{m}^{2} /$ day (of $\mathrm{Sb}^{\mathrm{V}}$ ) $(22.4-26.6 \mathrm{mg} / \mathrm{kg} / \mathrm{day})$, gradually increasing the daily dose during the first 3-4 days of therapy, is at least as effective as two 15-day courses or a 28-day course with $20 \mathrm{mg}$ of $\mathrm{Sb}^{\mathrm{V}}$ (the WHO recommended treatment) [2]. Resistance to pentavalent antimonials has been documented in India and Sudan [4], although it does not seem to be a problem in our region; we did, however, observe two relapses.

A 6-day course (on days 1-5 and 10) of therapy with $\mathrm{L}-\mathrm{AmB}$ was shown to be effective and safe in children with VL. The cost of this regimen for a $15 \mathrm{~kg}$ child in
We believe that the differences between American and Mediterranean visceral leishmaniasis are due only to the habits and characteristics of their vectors

c An increasing number of cases of visceral leishmaniasis have been diagnosed in adults with concomitant HIV infection in Spain, Italy, and southern France

?, suspected or not determined based on the available data

our hospital is about $\$ 900$, while the cost of a 21 -day course of meglumine antimoniate $\left(25 \mathrm{mg} / \mathrm{kg} /\right.$ day of $\left.\mathrm{Sb}^{\mathrm{V}}\right)$ for the same child is $\$ 10$; however, taking into account the length of hospitalization (with a cost of $\$ 150$ per day) and the risk of acquiring nosocomial infections, in our opinion the balance seems to favor the use of $\mathrm{L}-\mathrm{AmB}$ as a first choice for the treatment of children with VL in industrialized Mediterranean countries. In this regard, we disagree with the recent Greek recommendation [14], since we do not believe that the outpatient administration of antimonials is feasible due to the potential fatal toxicities of these drugs.

Unfortunately, meglumine antimoniate is currently the only drug approved in Italy for the treatment of VL. However, a multicenter randomized controlled trial (meglumine antimoniate vs. L-AmB) is now under way in Italy in which a pharmaco-economic evaluation also will be performed.

Acknowledgments This study was supported by AILMI (Associazione Italiana per la Lotta contro le Malattie Infettive. We are very grateful to Prof. A.D.M. Bryceson for his helpful discussion on the manuscript. 


\section{References}

1. Cascio A, Gradoni L, Scarlata F, Gramiccia M, Giordano S, Russo R, Scalone A, Camma C, Titone L: Epidemiologic surveillance of visceral leishmaniasis in Sicily, Italy. American Journal of Tropical Medicine and Hygiene (1997) 57:75-78

2. World Health Organization Expert Committee: Control of the leishmaniasis. WHO Technical Report Series, no. 793. WHO, Geneva (1990)

3. Gradoni L, Bryceson A, Desjeux P: Treatment of Mediterranean visceral leishmaniasis. Bulletin of the World Health Organization (1995) 73:191-197

4. Murray HW: Treatment of visceral leishmaniasis (kala-azar): a decade of progress and future approaches. International Journal of Infectious Diseases (2000) 4:158-177

5. Di Cristina G, Caronia G: Sulla terapia della leishmaniosi interna. Pathologica (1915) 7:82-83

6. Davidson RN, di Martino L, Gradoni L, Giacchino R, Russo R, Gaeta GB, Pempinello R, Scotti S, Raimondi F, Cascio A, Prestileo T, Caldeira L, Wilkinson RJ, Bryceson ADM: Liposomal amphotericin B (AmBisome) in Mediterranean visceral leishmaniasis: a multicentre trial. Quarterly Journal of Medicine (1994) 87:75-81

7. Davidson RN, di Martino L, Gradoni L, Giacchino R, Gaeta GB, Pempinello R, Scotti S, Cascio A, Castagnola E, Maisto A, Gramiccia M, di Caprio D, Wilkinson RJ, Bryceson AD: Short-course treatment of visceral leishmaniasis with liposomal amphotericin B (AmBisome). Clinical Infectious Diseases (1996) 22:938-943

8. di Martino L, Davidson RN, Giacchino R, Scotti S, Raimondi F, Castagnola E, Tasso L, Cascio A, Gradoni L, Gramiccia M, Pettoello-Mantovani M, Bryceson AD: Treatment of visceral leishmaniasis in children with liposomal amphotericin B. Journal of Pediatrics (1997) 131:271-277

9. Pearson RD, Sousa AQ, Jeronimo MB: Leishmania species: visceral (kala-azar), cutaneous, and mucosal leishmaniasis. In: Mandell GL, Bennett JE, Dolin R (eds): Principles and practice of infectious diseases. Churchill Livingstone, Philadelphia (2000) pp 2831-2845
10. Magil AJ: Leishmaniasis. In: Strickland TG (ed): Hunter's tropical medicine and emerging infectious diseases. Saunders, Philadelphia (1999) pp 665-687

11. Alvar J, Canavate C, Gutierrez-Solar B, Jimenez M, Laguna F, Lopez-Valez R, Molina R, Moreno J: Leishmania and human immunodeficiency virus coinfection: the first 10 years. Clinical Microbiology Reviews (1997) 10:298-319

12. Maurìcio IL, Stothard JR, Miles MA: The strange case of Leishmania chagasi. Parasitology Today (2000) 16:188-189

13. Minodier P, Piarroux R, Garnier JM, Unal D, Perrimond H, Dumon H: Pediatric visceral leishmaniasis in southern France. Pediatric Infectious Disease Journal (1998) 17:701-704

14. Maltezou HC, Siafas C, Mavrikou M, Spyridis P, Stavrinadis C, Karpathios T, Kafetzis DA: Visceral leishmaniasis during childhood in southern Greece. Clinical Infectious Diseases (2000) 31:1139-1143

15. Minodier P, Garnier JM: Childhood visceral leishmaniasis in Provenza. Archives de Pediatrie (2000) 7:572-577

16. Perea WA, Ancelle T, Moren A, Nagelkerke M, Sondorp E: Visceral leishmaniasis in southern Sudan. Transactions of the Royal Society of Tropical Medicine and Hygiene (1991) 85:48-53

17. Zijlstra EE, Siddig Ali M, el-Hassan AM, Hofland HW, el-Toum I, Satti M, Ghalib HW: Clinical aspects of kala-azar in children from the Sudan: a comparison with the disease in adults. Journal of Tropical Pediatrics (1992) 38:17-21

18. Gramiccia M, Gradoni L, Angelici MC: Epidemiology of Mediterranean leishmaniasis caused by Leishmania infantum: isoenzyme and kDNA analysis for the identification of parasites from man, vectors and reservoirs. In: Hart DT (ed): Leishmaniasis. Plenum Publishing (1989) pp 21-37

19. Schilirò G, Russo A, Musumeci S, Sciotto A: Visceral leishmaniasis following a skin lesion in a six-year-old Sicilian girl. Transactions of the Royal Society of Tropical Medicine and Hygiene (1978) 72:656-657

20. Pampiglione S: Leishmaniosi cutanea seguita da kala-azar in adulto in provincia di Teramo (Abruzzi). Parassitologia (1971) $13: 231-239$ 